\title{
Constraints to Forest Policy Implementation in the Southwest Nigeria: Causes, Consequences and Cure
}

\author{
Faleyimu O. I ${ }^{1, *}$, Agbeja B. $\mathbf{O}^{2}$ \\ ${ }^{1}$ Deprtment of Biological Sciences, Ondo State University of Science and Technology, Okitipupa, Nigeria \\ ${ }^{2}$ Department of Forest Resources Management, University of Ibadan, Nigeria
}

\begin{abstract}
There are many hindrances to effective implementation of the forest policy in the South-Western Nigeria. This paper examines the constraints to forest policy implementation in the South-Western Nigeria and their impacts on forest development. Primary data were collected in the six States in Southwestern Nigeria. The States were stratified into thirty one Forestry Administrative Zones viz: Ekiti, 4; Lagos, 5; Ogun 4; Ondo, 8; Osun, 6; and Oyo, 4. One forest officer in charge of each zone and one in charge of each State headquarter were selected to give 37 Forest Officers. In addition, $10 \%$ registered timber contractors (94), registered sawmillers (167); plank sellers (115); and villagers within and outside the chosen forest reserves (97) totaling 510 respondents were randomly selected for enumeration using structured questionnaires. The data were analyzed using descriptive statistics and Chi-square $\left(\chi^{2}\right)$ at 0.01 level of significance. Constraints identified include: illegal felling and poaching $\left(\chi^{2}=333.74, p<0.01\right)$, lack of effective supervision and coordination $\left(\chi^{2}=28.72, p<0.01\right)$, inadequate information from the policy makers $\left(\mathrm{X}^{2}=109.84, \mathrm{p}<0.01\right)$, lack of complementary roles by all forestry stakeholders $\left(\chi^{2}=84.03, p<0.01\right.$, non-encouragement of private forest plantation $\left(\chi^{2}=36.28, p<0.01\right)$ and undefined forestry programmes $\left(\chi^{2}=17.69, p<0.01\right)$ but with a low degree of dependence $(V=0.27)$. In conclusion, it is recommended that if the on-going deforestation, forest depletion and degradation are to be curbed, it is essential to have a proactive and forward-looking policies anticipating economic, social and environmental changes to guide the development of the forest sector.
\end{abstract}

Keywords Constraints, Policy implementation, illegal felling and poaching, deforestation

\section{Introduction}

Policy is a direction for development. Simply put, policy is definite course of action adopted for the sake of expediency. It is a course of action adopted and pursued by a government, political party, etc (1). Achieving sustainable forest management will only be possible when sensible rules and regulations are enforced and adhered to (2). In the South-Western Nigeria, the sustained yield principle has been jettisoned thus effectively negating forest policy prescriptions. Nevertheless, in a situation of inconsistent and inappropriate forest policies, almost all the objectives laid down in the recommended policies for forestry sector in Nigeria are thwarted as well as haphazardly implemented (3, 4). Forests constitute a renewable source of valuable raw materials that are currently in increasing demand and that have little prospect of being replaced by economically and environmentally acceptable substitutes. A constructive and rational attitude by people of all kinds toward forests, forestry and forest industries depends on understanding, skills and scientific knowledge (5). Without citing examples of the

* Corresponding author:

orimoloyespecial@yahoo.com (Faleyimu, O.I)

Published online at http://journal.sapub.org/re

Copyright (C) 2012 Scientific \& Academic Publishing. All Rights Reserved misuse of public funds, it is no exaggeration to say that the proportion of revenue allotted by governments to forestry is often inadequate or unproductive. If the economic channels favoured by the State involve too much waste, it is logical to conclude that they must be curtailed (6). The political support of those responsible for implementing the law is a vital factor (5). It is essential that appropriate mechanisms, process and tools are put in place now to ensure the sustainable and fair use of forest resources (2).

This paper therefore examines the constraints to forest policy implementation in the South-Western Nigeria and their impact on forestry development.

\section{Methodology}

\subsection{The Study Area}

The study area is south western Nigeria which consist of Lagos, Ogun, Oyo, Osun, Ondo and Ekiti states. It is also known as the south West geographical zone of Nigeria. The area lies between longitude $2^{0} 31^{1}$ and $6^{0} 00^{1}$ East and Latitude $6^{0} 21^{1}$ and $8^{0} 37^{1} \mathrm{~N}(7)$ with a total land area of 77,818 $\mathrm{km}^{2}$ and a projected population of 28, 767, 752 in 2002 (8). The study area is bounded in the East by Edo and Delta states, in the North by Kwara and Kogi states, in the West by the Republic of Benin and in the south by the Gulf of Guinea. The study area has 85 constituted Forest reserves with a 
forest area cover of 842,499 hectare (Table 1).

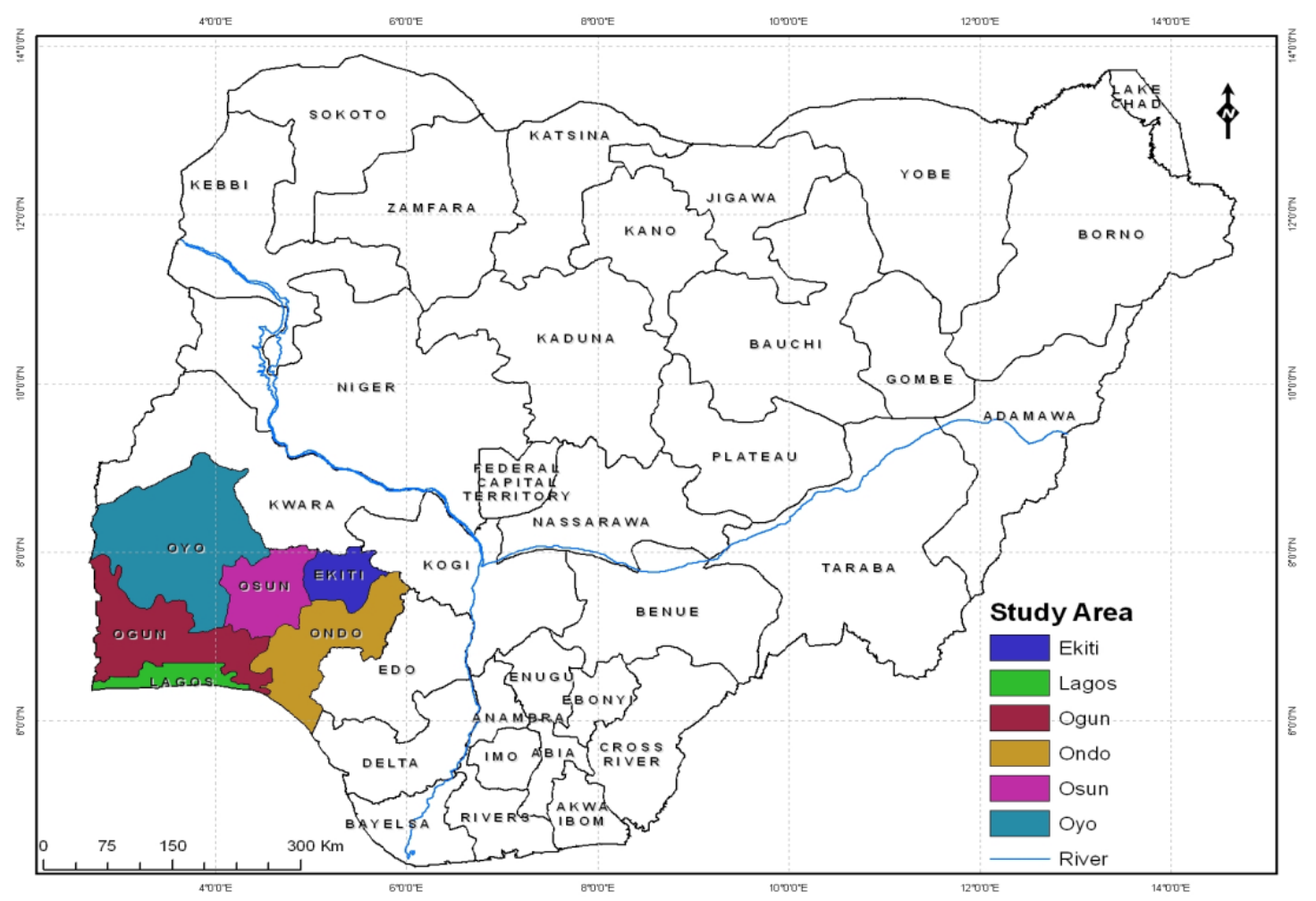

Figure 1. shows the position of the study area in the map of Nigeria

Table1. South Western States and their Land Area

\begin{tabular}{|c|c|c|c|c|c|}
\hline State & $\begin{array}{c}\text { Total land Area } \\
\left(\mathrm{Km}^{2}\right)\end{array}$ & $\begin{array}{c}\text { No of Forest } \\
\text { Reserve }\end{array}$ & $\begin{array}{c}\text { Area of Forest } \\
\text { Reserves (Ha) }\end{array}$ & $\begin{array}{c}\text { Number of local } \\
\text { Government Area }\end{array}$ & $\begin{array}{c}\text { Forest reserve or } \\
\text { land area ratio (\%) }\end{array}$ \\
\hline Osun & 9,491 & 11 & 91,268 & 30 & 9.62 \\
\hline Ondo/Ekiti & 20,451 & 37 & 305,541 & $17 \& 16$ & 14.94 \\
\hline Ogun & 16,086 & 9 & 275,362 & 20 & 17.12 \\
\hline Oyo & 27,848 & 18 & 169,173 & 33 & 6.06 \\
\hline Lagos & 3,939 & 03 & 6,873 & 20 & 0.30 \\
\hline
\end{tabular}

Source: (9)

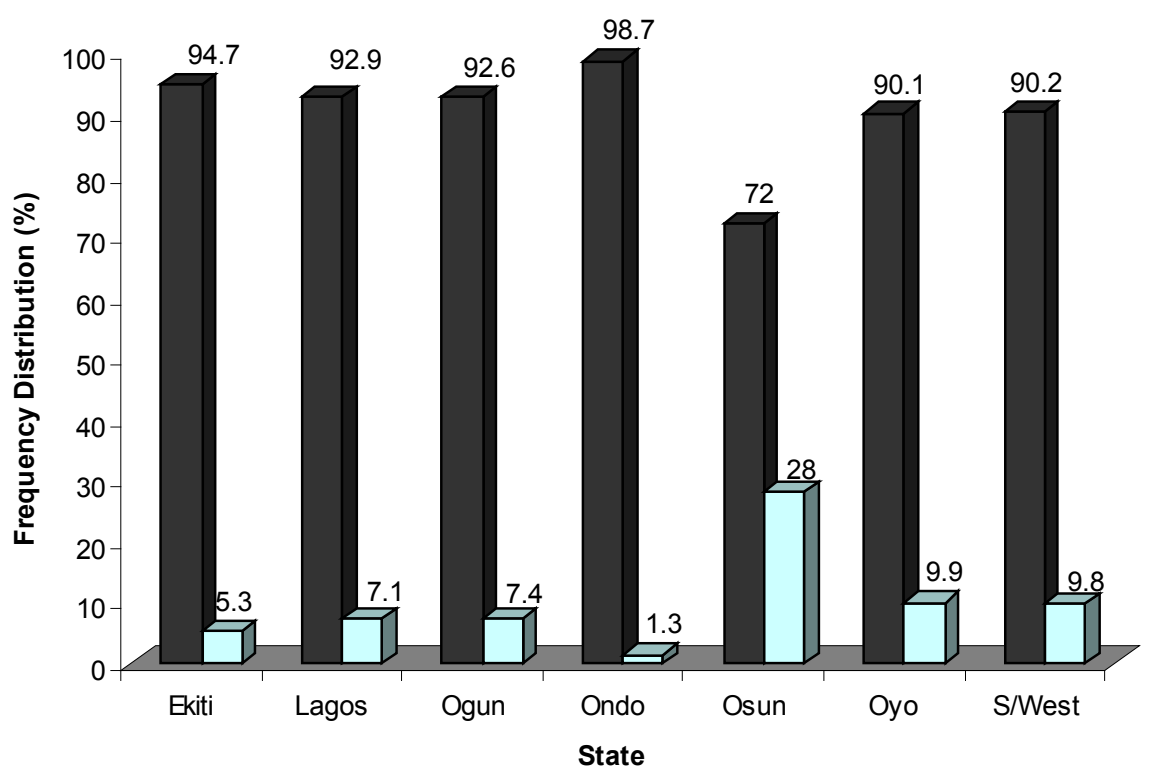

$\square$ Agreed

$\square$ Disagreed

Figure 2. Frequency Distribution Stakeholders Perception of the Effect of illegal Felling and poaching on Effective Forest Policy Implementation 


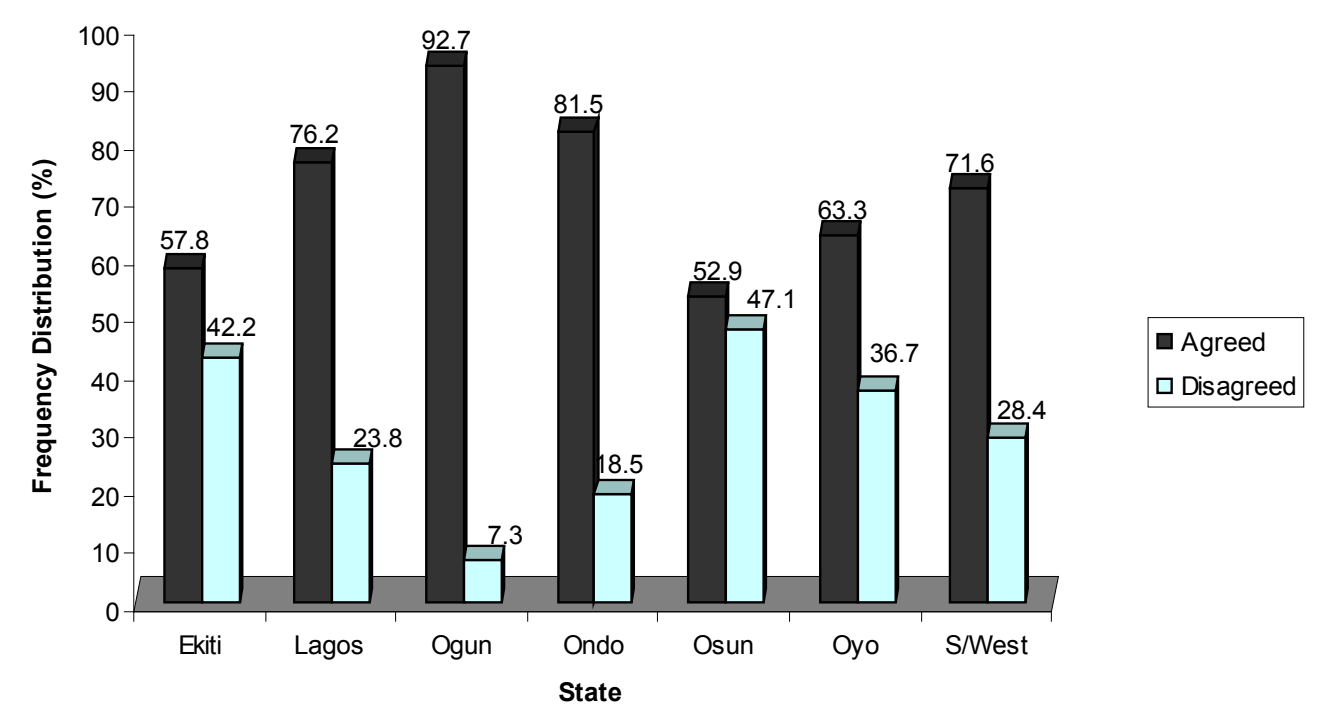

Figure 3. Frequency Distribution of Stakeholders Perception of the Effect of Effective Supervision, Coordination and Control on Effective Forest Policy

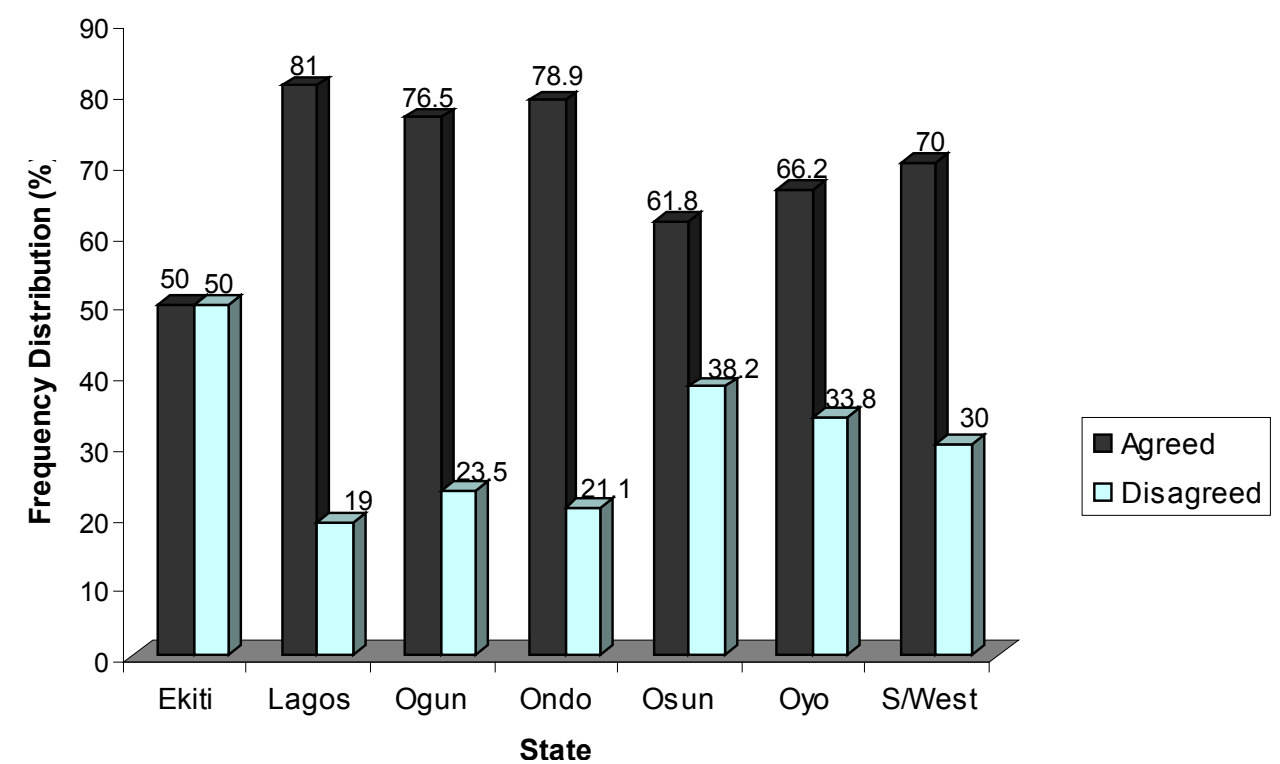

Figure 4. Frequency Distribution of Stakeholders Perception of the Effect of Inadequate Information from the Policy Makers on Effective Forest Policy Information

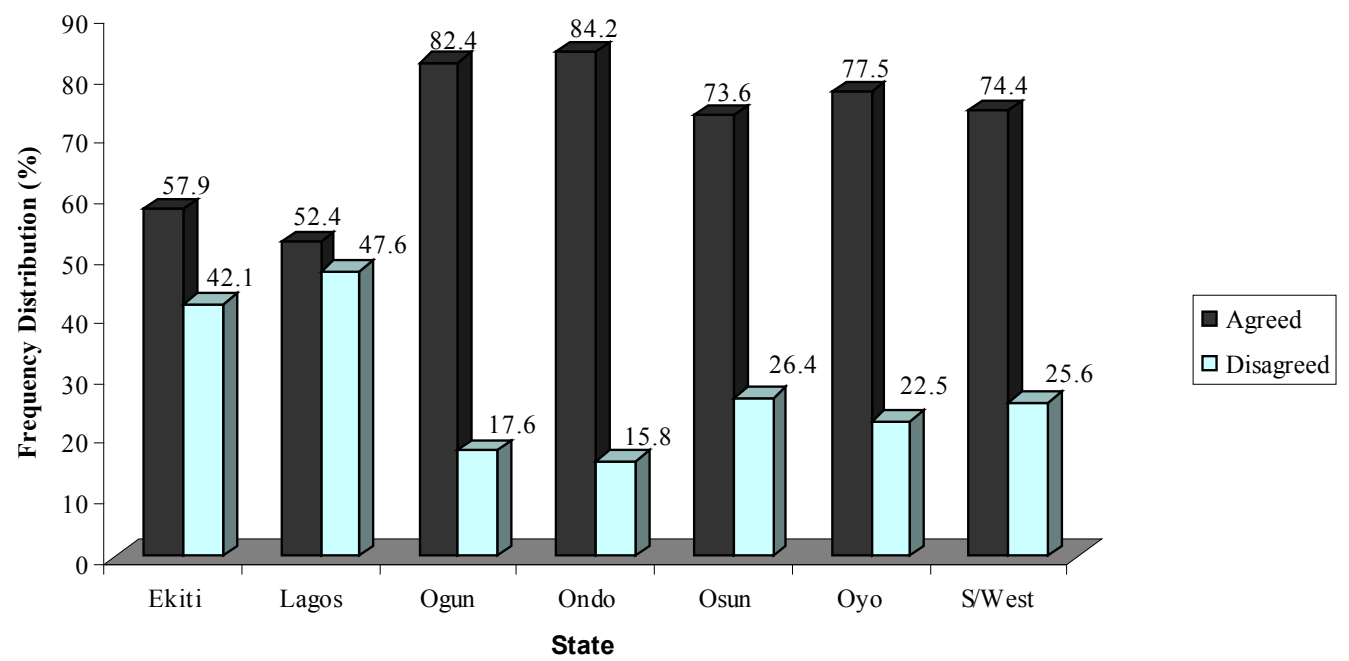

Figure 5. Frequency Distribution of Stakeholders Perception of the Effect of Lack of Complementary Roles by all Forestry Stakeholder on Effective Forest Policy Implementation 


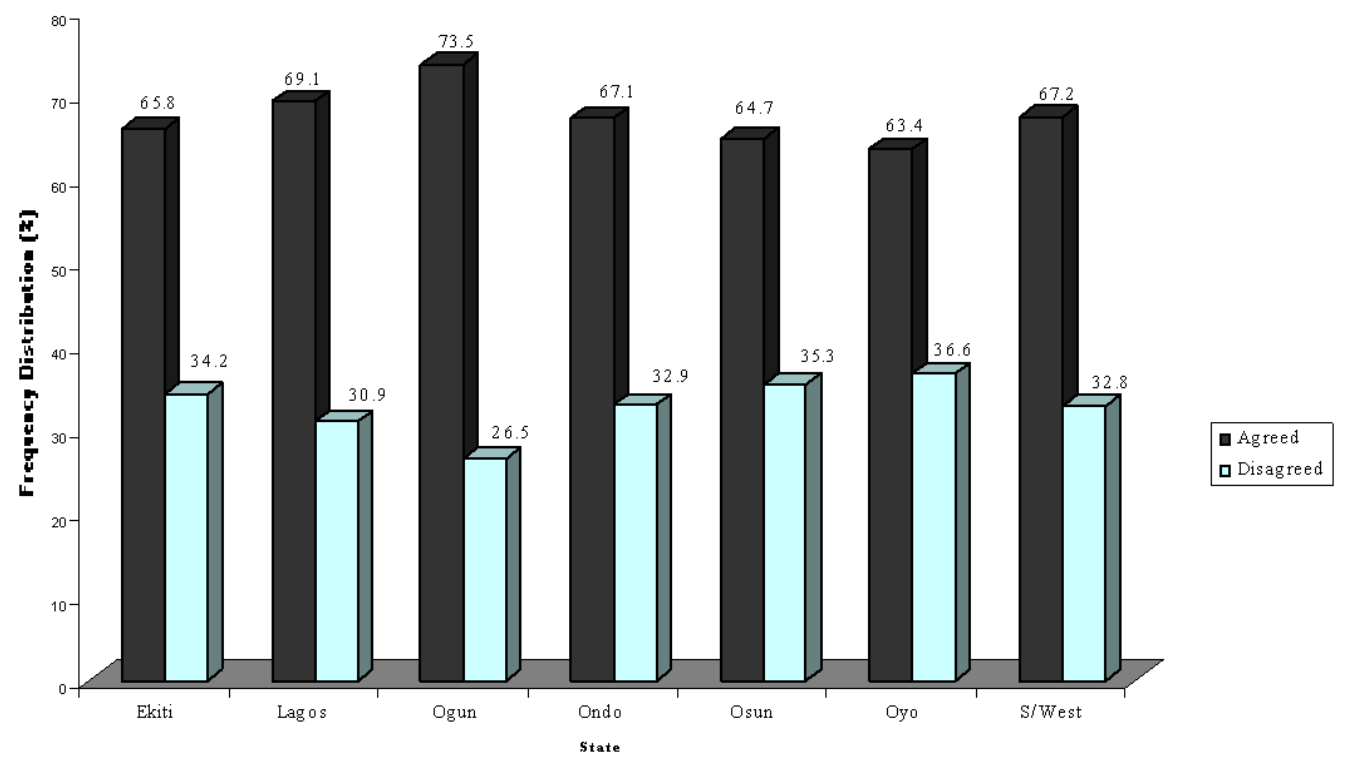

Figure 6. Frequency Distribution of Stakeholders Perception of Non-specific Encouragement of Private Forest Plantation on Effective Forestry Policy Implementation

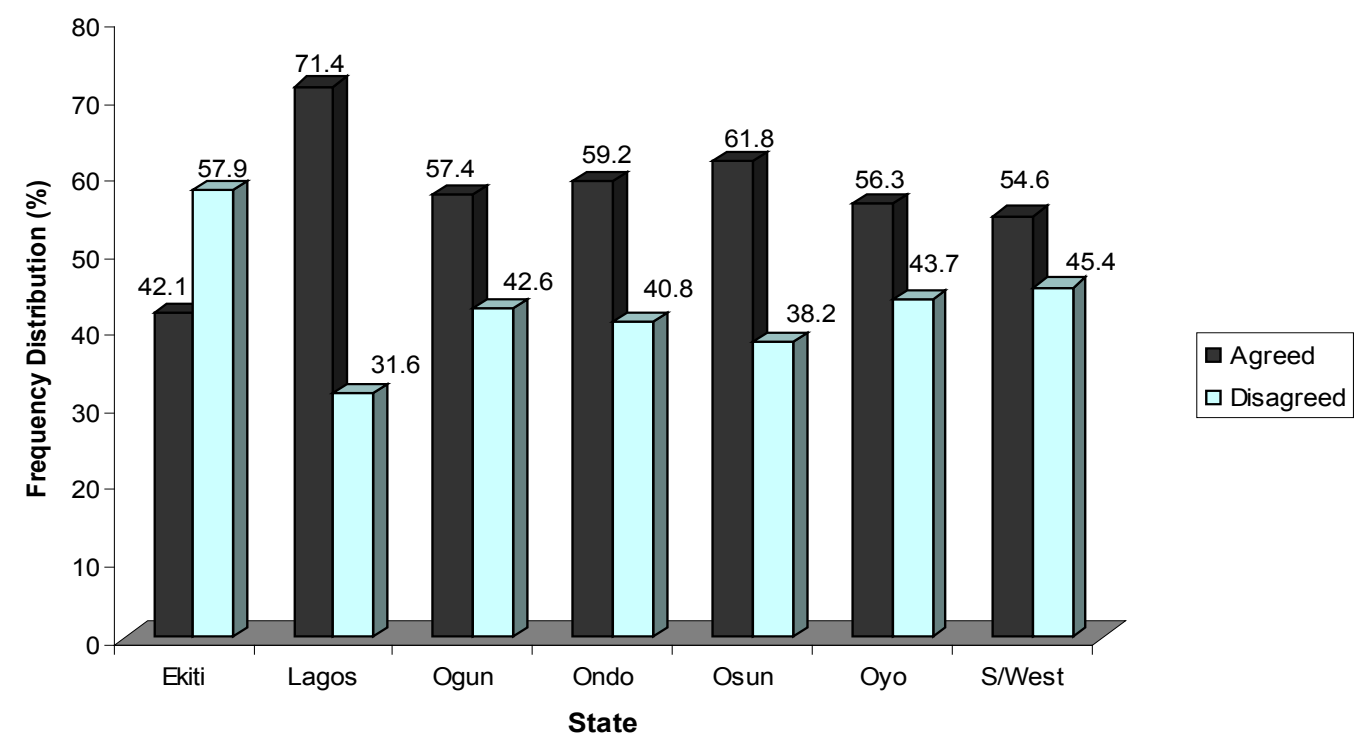

Figure 7. Frequency Distribution of Stakeholders Perception of the Effect of Undefined Forestry Programme Objectives on Effective Forest Policy Implementation

\subsection{Climate and Vegetation of the Study Area}

The climate of Southwest Nigeria is tropical in nature and it is characterize by wet and dry seasons. The temperature ranges between $21^{\circ} \mathrm{Cand} 34^{\circ} \mathrm{C}$ while the annual rainfall ranges between $1500 \mathrm{~mm}$ and $3000 \mathrm{~mm}$. The wet season is associated with the Southwest monsoon wind from the Atlantic Ocean while the dry season is associated with the northeast trade win from the Sahara desert. The vegetation is Southwest Nigeria is made up of fresh water swamp and mangrove forest at the belt, the low land in forest stretches inland to Ogun and part of Ondo state while secondary forest is towards the northern boundary where derived and southern Savannah exist (8).

\subsection{Data Collection}

Field survey, which entails detailed appraisal of the various aspects of the forest policy implementation, were carried out through the use of structured questionnaire containing both open and close ended questions and opinion/target group discussions to gather relevant data from forest stakeholders in South-Western Nigeria.

\subsubsection{Population and Sample}

Primary data needed for the study were collected through multistage random sampling where the study area is first stratified into six states, and each state were further stratified into forestry administrative Zones. Ten percent of each of the 
respondents was selected. The Zones in each of the states are as follows as shown in table 2 .

Table 2. Zonal Offices

\begin{tabular}{|c|c|}
\hline States & Zones \\
\hline Ekiti & 4 Zones (Ado, Ikere, Ikole Ido and Ekiti ) \\
\hline Lagos & 5 Zones (Badagry, Epe, Ikeja, Lagos and Ikorodu) \\
\hline Ogun & 4 Zones (Egba, Yewa, Remo and Ijebu \\
\hline Ondo & $\begin{array}{c}\text { 8 Zones (Akure South, Akure North, Idanre, Ore, } \\
\text { Owo, Ikare, Ifon, and Ondo) }\end{array}$ \\
\hline Osun & 6 Zones (Ife, Ilesa, Ikirun, Osogbo, Iwo and Ede) \\
\hline Oyo & 4 Zones (Ibadan, Oyo, Saki and Ogbomosho) \\
\hline
\end{tabular}

\subsection{Data Analysis}

The primary and secondary data collected were processed into suitable format for various analyses. Data analysis involved non-parametric tests using appropriate statistical tools. The following statistical analyses were carried out:

\subsubsection{Descriptive Statistics}

This involved frequency analysis, percentages, cross tabulations and bar graphs to depict trends in forest policy implementation in the South-Western Nigeria.

\subsubsection{Chi-square $\left(\mathrm{X}^{2}\right)$ Test}

$$
\mathrm{X}^{2}=1 / \mathrm{G} \sum \frac{\left(\mathrm{Ga}_{\mathrm{ij}}-\mathrm{S}_{\mathrm{i}} \mathrm{T}_{\mathrm{j}}\right)^{2}}{\mathrm{~S}_{\mathrm{i}} \mathrm{T}_{\mathrm{j}}} \text { with (r-1) (c-1) degrees of free- }
$$

dom equation(1)

where

$\mathrm{X} 2$ = estimated chi-square value

$\mathrm{G}=$ sum of all the observation

Aij = individual observation in ith row and jth column

$\mathrm{Si}=$ sum of individual observation in ith row

$\mathrm{T} j=$ sum of individual observation in $\mathrm{jth}$ row

$\mathrm{R}=$ number of rows

$\mathrm{E}=$ number of columns

(10)

\section{Results}

The result of the research work is shown below.

\subsection{Illegal Fellers and Poachers}

Illegal felling of trees and poaching are twin evils affecting resource management in the forestry sub sector. Result of the pooled data from the southwest indicated that $90.2 \%$ of the respondent agreed that illegal felling and poaching are problems of forest policy implementation while only $9.8 \%$ of the respondent disagreed (figure 2). The chi-square analysis reveals that illegal felling and poaching have significant relationship with effective forest policy implementation $\left(X^{2}=333.74, p<0.01\right)$.

\subsection{Lack of Effective Supervision and Coordination}

The long-term fortunes of forestry depend largely on the institutions in place as well as the performance of the managers. The pooled data from the South-West indicated that $63.7 \%$ of the respondents agreed that lack of effective supervision, coordination and control is a problem of forest policy implementation while $36.3 \%$ disagreed (figure 3 ). The chi-square analysis revealed that lack of effective supervision, coordination and control have significant relationship with effective forest policy implementation $\left(\chi^{2}=28.72\right.$, $\mathrm{p}<0.01$ ).

\subsection{Inadequate Information from the Policymaker}

The Nigerian community is yet to be carried along in the forest policy formulation and implementation. The findings showed that $70 \%$ of the respondents in the south-West Nigeria agreed that inadequate of information form the policy makers constitute a problem to effective forest policy implementation while $30 \%$ of the respondents disagreed (figure 4). The chi-square analysis revealed that inadequate information from the policy makers have significant relationship with effective forest policy implementation $\left(X^{2}=109.84\right.$, $\mathrm{p}<0.01)$.

\subsection{Lack of Complementary Roles by all Forestry Stakeholders in Forestry Affairs}

This has been identified as a clog in the wheel of forest policy implementation in the South-West Nigeria. Complementary roles by other stakeholders refer to assistance that can be rendered by them to the forest service to be able to fulfill the objectives laid down. The pooled data from the south west indicated that $74.4 \%$ of the respondents agreed that lack of complementary roles by the forestry stakeholders is a problem to effective forest policy implementation while $25.6 \%$ of the respondent disagreed (figure 5). The chi-square analysis result of the respondents indicated that lack of complementary roles by all forestry stakeholders have significant relationship with effective forest policy implementation $\left(\chi^{2}=84.03, p<0.01\right)$.

\subsection{Encouragement of Private Forest is Non-Specific}

It is high time the general public is carried along to invest in forestry projects by extension personnel and employing mass media could be of great help. The pooled data from the south west revealed that $67.2 \%$ of the respondents agreed that non encouragement of private forest participation is a problem of effective forest policy implementation while $32.8 \%$ of the respondents disagreed (figure 6). The chi-square analysis indicated that non-encouragement of private forest plantation have significant relationship with effective forest policy implementation $\left(\chi^{2}=36.28, p<0.01\right)$.

\subsection{Undefined Forestry Objectives}

Most of the respondents in each State in the South-West Nigeria are yet to fully understand the objective of forest policy. It would seem obvious that for a programme to succeed the goals and objectives must be clearly stated without such specifics, a programme result may be well disappoint- 
ing. The pooled data from the South-West Nigeria indicated that $54.6 \%$ of the respondents agreed that lack of defined forestry programme is a problem of forestry policy implementation while $45.4 \%$ of the respondent disagreed (figure 7). The chi-square analysis revealed that lack of define forestry programmes have significant relationship with effective forest policy implementation $\left(\chi^{2}=17.69, \mathrm{p}<0.01\right)$.

\section{Discussion}

The study revealed that illegal felling and poaching are twin evils affecting resources management in the forestry sub-sector. The forest reserves and wildlife sanctuaries are under severe illegal exploitation. (11) reported that in the last years of military, there was collusion with foreigners in felling of teak trees across most plantations established in the country in the 1950s and 1960. Illegal logging may generate employment in the short term but in the longer term it can contribute to the depletion of timber resources and the subsequent collapse of forest industries. Every year developing country governments lose billions of dollars in revenues due to illegal tax evasion in the forestry sector and unauthorized timber harvesting in public owned forest (12). Seyer (13) reported that when local people complain about illegal forestry activities, the implicated parties often respond with threats or even violence. In addition the corrupt government officials sometimes take action against local people to protect their interests or those of illegal loggers and poachers. Illegal forestry activities cause environmental damage and threatens forests which many people depend on. Though many tropical countries in Africa, Asia and Latin America rely on logging for exports earnings, illegal logging costs forest country governments at least US $\$ 10-15$ billion a year - an amount greater than total World Bank lending to client countries and greater than total annual development assistance in public education and health (14). According to (15), illegal logging costs Indonesia approximately US \$ 60 million annually, while (16) reported that the direct financial losses to the government of Hordurasand Nicaragua due to clandestine logging have been estimated at US \$11-18 million and US \$ 4-8million, respectively. It is also important to remember that illegal logging is not confined to the developing countries. The Russian Federation is a major timber producer and exports, and estimates of the extent of illegal logging range from $20-30$ percent of the country as a whole, to around $40-50$ percent in particular areas of Siberia (17).The study revealed that ineffective supervision, coordination and control is a major problem for forest policy implementation in the southwest except in Lagos and Ogun State. The long term fortunes of forestry depends largely on the institutions in place as well as the performance of the managers $(18,19)$. It means that irrespective of the sustainability strategy and the enabling environment, the human role is indispensable. Also accountability and transparency are important component of effective supervision coordination and control. The study revealed that inadequate information from policy makers is a problem of forest policy implementation. The over whelming influence and impact of communication and information for the smooth running of business has been acknowledge (20). Such information should not be only technically focused but should include economic data, policy Statement and regulations guiding the use of such resources. Many researchers and practionners have acknowledged radio as the most widely used information dissemination medium. The reason for its wide acceptability may not be unconnected with its affordability and ease of operation. Hence its audience is not limited to the literate and mostly urban dwellers but also to people in remote parts of the world. Other advantages of radio include its immediacy as well as its independence on literacy. (21) and (22) reported the wide use of radio for disseminating information to farmers. Several channels such as extension agents, individuals, farmer - to - farmer contact, print media (newspaper, magazines, newsletters, leaflets, pamphlets and posters) and electronic media (radio, television, film, slides, and film strips) have been widely used to disseminate information to the public $(23,24,25$ and 26). The study revealed that lack of complementary roles by all forestry stakeholders in forestry affairs is one of the major problems of effective forest policy implementation in the south west Nigeria. It can be inferred from the result that forestry extension agent should be strengthened to carry the stakeholders along in all the various forestry programmes. Employing various mass media such as radio will also be of great assistance to solving a problem of this. The formulation of future forest policy for the country should be subjected to public debate at various levels so that such a policy will effectively cater for the interest of the greater majority of the people. Inputs by the local communities should be viewed seriously and incorporated if they are to participate in the execution of the policy. The study revealed that most of the respondents are not well encourage to invest in forestry project. Except for very few isolated cases, there has been very little private participation in forest production. The emphasis of the private sector in Nigeria as against what obtain in Europe and the American is mainly on exploitation, processing and utilization of forest products, there by further contributing to deforestation of the dwindling forest (27). (27) further emphasize that private ownership of forestry is not a venture of the get-rich-quick type of investors because of the long period of gestation. A private forest owner must be sort of sympathetic-at-heart for the course of plants and animal, like a livestock keeper. Many of the respondents in each of the State in the Southwest are yet to fully understand the objective of the forest policy Statement. This however, brought to the limelight why forestry extension services needed to be strengthened in order to obtain maximum cooperation from the stakeholders towards sustainable forest management. Such extension services should be aimed at assisting the stakeholder, to articulate their needs, their environmental problems and their perceptions of possible solutions to the identified problems in the same way, the communities would be integrated into natural resources management and thereby be convinced that the programmes 
drawn up are relevant to their needs and beneficial to them. This would further given them a sense of responsibility towards ensuring the success of whatever initiative that is embarked upon. The extension programme should also involve in training activities for the stakeholders through short-terms courses, field visits and practical demonstration in such areas as tree tending techniques, maintenance of hand tools and sustainable harvesting practices. The controversies over what policies we should follow are so stimulating and the problems of implementing and executing them so challenging that once a choice has been made and feasible means developed for effectuating it, it could be felt that the problem has been 'solved' and can now look for fresh "issues" to conquer. But in actual fact, the task may have just begun. For a policy is only an accepted course of action for achieving some objective. And this policy, no matter how good it looks today, may prove with time and increased knowledge to be a poor means of attaining that objective, or it may have unforeseen side effect which will ultimately lead us to conclude that it is a "bad" policy. In the same way, the implementing techniques and executing arrangements that now appear so promising may with use prove to be ineffective or at least inefficient. Because of this it is very important that both policies and programmes be subject to rather continuous review. (28) asserts that changes in policies and programmes are inevitable. They will be dealt with much more effectively if provision is made for anticipating and meeting them rather than waiting for crises to develop.

\section{Conclusions}

In conclusion, it is recommended that if the on-going deforestation, forest depletion and degradation are to be curbed, it is essential to have a proactive and forward-looking policy anticipating economic, social and environmental changes to guide the development of the forest sector.

\section{REFERENCES}

[1] Agbeja B.O. 2004, The need to link State and Federal Forest Policies and Institution in Nigeria. In rebuilding African capacity for Agricultural Developments. The role of tertiary Education. African Network for Agroforestry Education (ANAFE) Kenya. Pp 95-105.

[2] ITTO 2005, Tropical Forest Update. Vol.15 Number 3. Pp32.

[3] Agbeja, B.O and Verinumbi 2006, Forest policy in Nigeria. Lead paper. Proceedings of the 31st Annual Conference of Forestry Association of Nigeria, (ed. L. Popoola). Held in Makurdi, Benue State. 20th- 25th November, 2006.

[4] Faleyimu, O.I, Agbeja, B.O. and Akinyemi, O 2008, Problems of effective forest policy implementation: the base of environmental degradation in southwestern Nigeria. Proceedings of the second international conference on scientific and industrial studies. Vol. 2 Num. 1 March 12-13, 2008.
UNILAG, Nigeria.

[5] Food, and Agriculture Organization (FAO) 1997. The State of the world's forests 1997 FAO, Rome. www.fao.org /forestry/foris/webview/forestry2/index.jsp:siteld $=3321 \&$ Langld $=1$. pp31-40.

[6] UNDP 2002, Annual Population Growth Rates (2002-2005). www.undp.org.

[7] Agboola S.A. 1979, An Agricultural Atlas of Nigeria, Oxford University Press, Nigeria 248.pp.

[8] National Population Commission, Abuja, Nigeria

[9] FOMECU 1998, Forest Resource Survey, Geomatics, Nigeria Ltd, Abuja.

[10] Ajewole,O. (2005, Social and Institutional Determinantsof Urban Forestry Development in Lagos. An Unpublished Ph.D Thesis. Submitted to the Department of Forest Resources Management, University of Ibadan. 206pp.

[11] Ajakaiye, D.O. 2001, Socio-Economic Issues in National Development: Forestry perspective. In forestry and National Development, proceedings of the 27th Annual Conference of FAN held in Abuja, FCT, 17-21st Sept., 2001. pp 235 - 245.

[12] FAO 2001, Global Forest Resources Assessment 2000. Main Report. FAO Forestry

[13] Seyer, J.F 2005, The earth scan Reader in Forestry and Development. Published by Earthscan, London. www. earthscan.uk. Pp 434.

[14] White, A and Martin, A (2002): who own the world's forestry? Forest Tenure and Public Forest in Transition. Forest/Center for International Environmental Law Washington DC.

[15] Baird M. 2001: Forest crime as a constraint on development. Lecture by country director The World Bank, 13 September 2001, Indonesia. http://wb/n 0018. worldbank org/eap /eap.nsf/Attachment/FLEG-58-2/\& File/8+2+ Mark + Baird Indonesia, + WB. Pdf.

[16] Richards, M., Del Gatto, F. and Lopez, G.A 2003, The cost of illegal logging in central America how much are the Honduran and Nicaraguan Governments losing? ODI, London www.odi.org.uk/talailegal/eng-evidence.ht.

[17] Brack, D., Gray, K; and Hayman, G. 2002, Controlling the International Trade in illegality Logged Timber and wood products. Royal institute of International Affairs (RIIA), London. www.riia.org/pdf/research/sdp/tradeinllegal timber pdf.

[18] Adeyoju, S.K. 2001, Forestry for National Development: A critique of the Nigerian Situation. Forestry and National Development. In the proceedings of the 27th Annual in the proceedings of the conference of Forestry Association of Nigeria management in Nigeria. In sustainable Forest Management in Nigeria: Lesson and prospects. Proceeding, of the 30th Annual conference of the Forestry ueled in Abuja, FCT, 17-21st Sept., 2001. pp55-67.

[19] Adeyoju S.K 2005, Institutional arrangements in support of sustainable forest Association of Nigeria held in Kaduna, Kaduna, State, Nigeria 07-11 Nov, 2005. pp 590-598.

[20] CTA 1997, Information for rural development the ACP States identify, their priorities, spore, No 67, CTA Wageningen. pp 
859

[21] Olowu, T.A and C.O Igodan 1989 Farmers media use pattern in six villages in Kwara State, Nigeria Rural Development in Nigeria, vol 3, No 2, pp 98-102.

[22] William, A. 1969, Effect of Radio. Nigeria journal of Rural Extension and Development Vol 1

[23] Olowu, T.A and Yahya M.K. 1992, Nigerian Journalist attitude towards coverage rural development news, Nigeria journal of Rural Extension and Development Vol 1, No 2 and 3 , pp 40-43.

[24] Omenesa, Z.E 1991, The effect of radio on agricultural development in the northern States of Nigeria, in Lawani, S.M and Babalaye T. (ed) Media Forum for Agriculture International Institute of Tropical Agriculture, Ibadan.
[25] Van de Ban, A.W and F.A Alawkins 1992, Agricultural Extension. Longman Scientific and Technical Publishers, England. 128p.

[26] Terry A Olowu and O.A Oyedokun (2000): Farmers' Accessibility of Agricultural Marketing Information. The case of Oinladun Radio Programme. Journal of Economics and Rural Development. Vol 14 No 1 pp 109-125.

[27] Dosumu M.A.A (2001): Private sector participation in forestry in Nigeria. The Eggua Experience. In the proceedings of the 27th Annual in the proceedings of the conference of Forestry Association of Nigeria dueled in Abuja, FCT, 17-21st Sept.,2001

[28] Worrel, A.C (1970): Principles of forest policy. Published by McGraw-Hill Book Company, New York. Pp 243. 